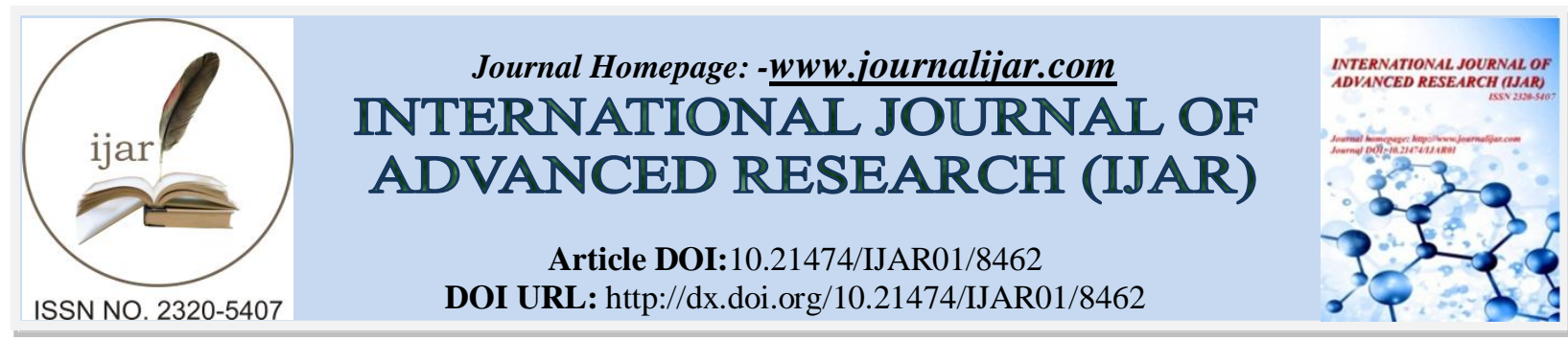

RESEARCH ARTICLE

\title{
YEASTS BIOTECHNOLOGIES APPLICATION AND THEIR INVOLVING IN AFRICAN TRADITIONAL FERMENTED FOODS AND BEVERAGES.
}

Iliassou Mogmenga ${ }^{1}$, Marius K. Somda ${ }^{1}$, Lewis I. Ezeogu ${ }^{2}$, Jerry Ugwuanyi ${ }^{2}$ and Alfred S. Traoré ${ }^{1}$.

1. Laboratory of Biotechnology for Food and Nutritional Sciences, Research Center in Biological Food and Nutrition Sciences (CRSBAN), Department of Biochemistry and Microbiology, University Ouaga I Pr Josph KY-ZERBO, 03BP 7021 Ouagadougou 03, Burkina Faso.

2. Department of Microbiology, Faculty of Biological Sciences, University of Nigeria Nsukka, 410001, Enugu state, Nigeria.

\section{Manuscript Info}

Manuscript History

Received: 02 December 2018

Final Accepted: 04 January 2019

Published: February 2019

Key words:-

Yeasts, Traditional fermented food, Value-added products, Biotechnology, Africa.

\section{Abstract}

Fermentation is an oldest method of food preservation and food nutritional value improving. It involves the concomitant action of one or more microorganisms, and yeasts are the one which play a significant role in African traditional fermented foods and beverages production. Traditional utilization of yeasts includes alcoholic beverages and fermented food production, but nowadays, with scientific methods developing, yeasts are implicated in medical, pharmaceutical, agriculture and other fields. Saccharomyces cerevisiae has been described as mankind's most domesticated organism; it is always exploited in several fields to produce value-added products by raw matter biotransformation and also in industry. Several studies which have been realized on Candida utilis demonstrated it potential utilization for human consumption and as animal fobbed. Modern applications of yeasts have been greatly expanded beyond classical applications. Saccharomyces cerevisiae and other non Saccharomyces yeast today are increasingly used for the heterologous production of enzymes and pharmaceutical proteins, biofuel, medical drugs... Yeasts have important roles in environmental applications such as bioremediation, organic wastes biotransformation and removal of heavy metals from waste - waters. Yeasts are also used in agriculture as biocontrol agents. Several chemical compounds can be produced using yeast as a biocatalyst. New developments in engineering yeast such as genetic modification have introduced novel capabilities to extend substrate range and produce new products so far yeast cannot produce. Yeast cell constituents at the nanoscale are the new fields of yeast nanobiotechnology thatnanotechniques are used for manipulation.

Corresponding Author:-Iliassou Mogmenga.

Address:-Laboratory of Biotechnology for Food and Nutritional Sciences, Research Center in

Biological Food and Nutrition Sciences (CRSBAN), Department of Biochemistry and

Microbiology, University Ouaga I Pr Josph KY-ZERBO, 03BP 7021 Ouagadougou 03, Burkina

Faso. 


\section{Introduction:-}

Yeasts are the major producer of biotechnology products worldwide, exceeding production in capacity and economic incomes than other groups of industrial microorganisms. Yeasts have wide ranging fundamental and industrial importance in scientific, food, medical and agricultural sciences (Johnson, 2013). Traditionally, yeasts have been used for several fermentations such as alcoholic beverages, biomass production and other fermented food. Fermented foods and beverages play an important role in the diet of African people, and the most often, these foods and beverages are produced at household level or at small industrial scale and are consequently often of varying quality and stability (Mogmenga et al., 2017; Tankoano et al., 2017). In Africa, cereals, legumes and tuber roots are the major raw materials which are mostly fermented but milk, fish and meat are also used (Fguiri et al., 2012; Greppi et al., 2013; Akabanda et al., 2014). Depending to the country or even the locality, various names may be given to the same products that are basically similar with slight variations on production and raw materials. Various yeast species are often isolated from Africa foods and beverages fermentations, and some examples of previously reported species are Candida lusitania, Cryptococcus laurentii, Saccharomyces cerevisiae, Candida kefyr, Issatchenkia orientalis, Kazachstania unisporus, Rhodotorula mucilaginosa, Candida pararugosa, Torulaspora delbrueckii, Geotrichum sp., Kazachstania unisporus, Geotrichum fragrans, Yarrowia lipolytica, Trichosporon gracile, Pichia membranifaciens...

For most reasons, yeasts are suitable for modern biotechnologies application. For example, yeasts offer the ease of microbial growth and gene manipulation allowed to understand many eukaryote-specific post-translational modifications, such as proteolytic processing, folding, disulfide bridge formation, and glycosylation (Cereghino and Cregg, 1999; Jans et al., 2017). Also, modern biotechnologies application of yeasts involve foreign proteins expressing for the pharmaceutical industry, the production of biofuel, organic acids, bioethanol, industrial enzymes, small molecular weight metabolites... (Türker, 2014). More recently, yeasts species including Pichia pastoris, Saccharomyces cerevisiae and others have been developed for heterologous proteins and enzymes production including pharmaceutical proteins, and as a model and fundamental organisms for the delineation of genes and their function in mammalian and human metabolism and disease processes (Cyert and Philpott, 2013; Johnson, 2013). New developments of yeast in engineering have introduced novel capabilities to extend substrate range and produce new products so far yeast can no produce. Saccharomyces cerevisiae is largest domesticated and still widely exploited yeast species in industrial today. This microorganism has become a valuable tool to study eukaryotic cell because he harbors many enzymes and pathways with counterparts in mammalian cells (Hatoum et al., 2012; Tomo et al., 2013; Mcfarland, 2015).

Several researchers have studied and reviewed yeasts application in food industries, chemical compound and biofuel production, complex wastes valorization, agricultural application, environmental application and yeasts medical application across the world (Seo et al., 2007; Rodríguez-Limas et al., 2011; Schisler et al., 2011; Watanabe et al., 2013; Scoma et al., 2017; Willaert, 2017). Many genera or species of yeasts have been reported in relation to various biotechnology applications and the usage of molecular tools in recent years has helped to clarify the nomenclatural confusion. The present review is an attempt to collate and review the updated information on the role of yeasts in African fermented foods and yeasts biotechnologies application.

\section{Yeast as food or food ingredients}

Yeast is one of the first domesticated microorganisms used in fermented foods production, foods and food ingredients in human alimentation in Africa (Cereghino and Cregg, 1999; Mogmenga et al., 2017). The role of yeasts in foods and beverages production is known for a long time. Several types of yeasts including Saccharomyces cerevisiae, Candida tropicalis, Candida utilis, Rhodotorula glutinis, Sporobolomyces patagonicus, Sporobolomyces roseus, Rhodotorula mucilaginosa, Yarrowia lipolytica, Kluyveromyces lactis, Geotrichum candidum ... are used for value - added products production (Dimova et al., 2010; Suman et al., 2015; Ouedraogo et al., 2017; Somda et al., 2017). Application of yeast starters has become a standard practice in the industrial fermentation for food and beverages and other products such as organic acids, amino acids, vitamins, lipids, carotenoid, glycerol... (Türker, 2014). Most of those compounds produced by yeasts are used in human foods and food ingredients.

Several studies carried out showed that those value - added products are produced by yeasts using raw materials of plant as well as animal origin. Indeed, mangoes, molasses, potatoes, sorghum, wheat, rice, paper industrial... wastes were used for value - added products production (Konlani et al., 1996; Wijeyaratne and Jayathilakf, 2000; Dimova 
et al., 2010; Somda et al., 2017). Saccharomyces cerevisiae is the most frequently involved yeast species in the production of yeast foods and food ingredients (Bhalla, 2017). Using yeasts for value added products production is related to the fact that yeasts are able to ferment a broad range of carbon substrate and generate secondary metabolites which can be used in several fields such as food, cosmetic, and pharmaceutical industries...

\section{Yeasts as Food}

Yeasts are the predominate microorganisms in most of the traditional fermented foods and beverages such as burukutu, merissa, bhatooru, seera, chhang, fufu, tape, ogi, puto, dosa, idli, papdam, kecap, laochao, warri, etc (Bhalla, 2017). In these traditional foods, yeast either alone or in association with bacteria and mould has substantial influence on taste, aroma, texture and nutritional value of the fermented products. Yeasts have been cultivated also as rich sources of protein, minerals, vitamins (particularly B vitamins), and other nutrients for humans and animals (Wijeyaratne and Jayathilakf, 2000; Ouedraogo et al., 2017). Several yeast species have been used for biomass production, including Candida utilis, other non-methylotrophic Candida spp., Saccharomycopsis fibuligera, Kluyveromyces spp., and Saccharomyces cerevisiae (Dimova et al., 2010; Ouedraogo et al., 2017; Somda et al., 2017). Methylotrophic, ethanol-utilizing, and fat and hydrocarbon-utilizing yeasts including species of Candida, Ogataea, Pichia, and Trichosporon have also been used for biomass production (Türker, 2014). Thus, yeasts play very important role in improving the nutrition and socio-cultural life of people living in rural and tribal areas of various countries across the world.

\section{Nutritional quality of yeasts}

Yeasts are a great nutritional value and can contain more than $60 \%$ of proteins and $15 \%$ of lipids (Dimova et al., 2010; Ouedraogo et al., 2017; Somda et al., 2017). Ouedraogo et al. (2017) obtained 54.8\% of protein with Candida utilis in Single Cell Protein (SCP) production using tubercules wastes as a substrate. The high rate of protein in yeasts show that yeasts can be used like food complement to increase nutritional value of certain food par example cereal food. Amino acids analysis from yeasts SCP shows that yeasts contain high rates of essential amino acid (Table 1). 
Tableau 1:-Amino acids contain in yeasts used for SCP production compared with some standard source of protein

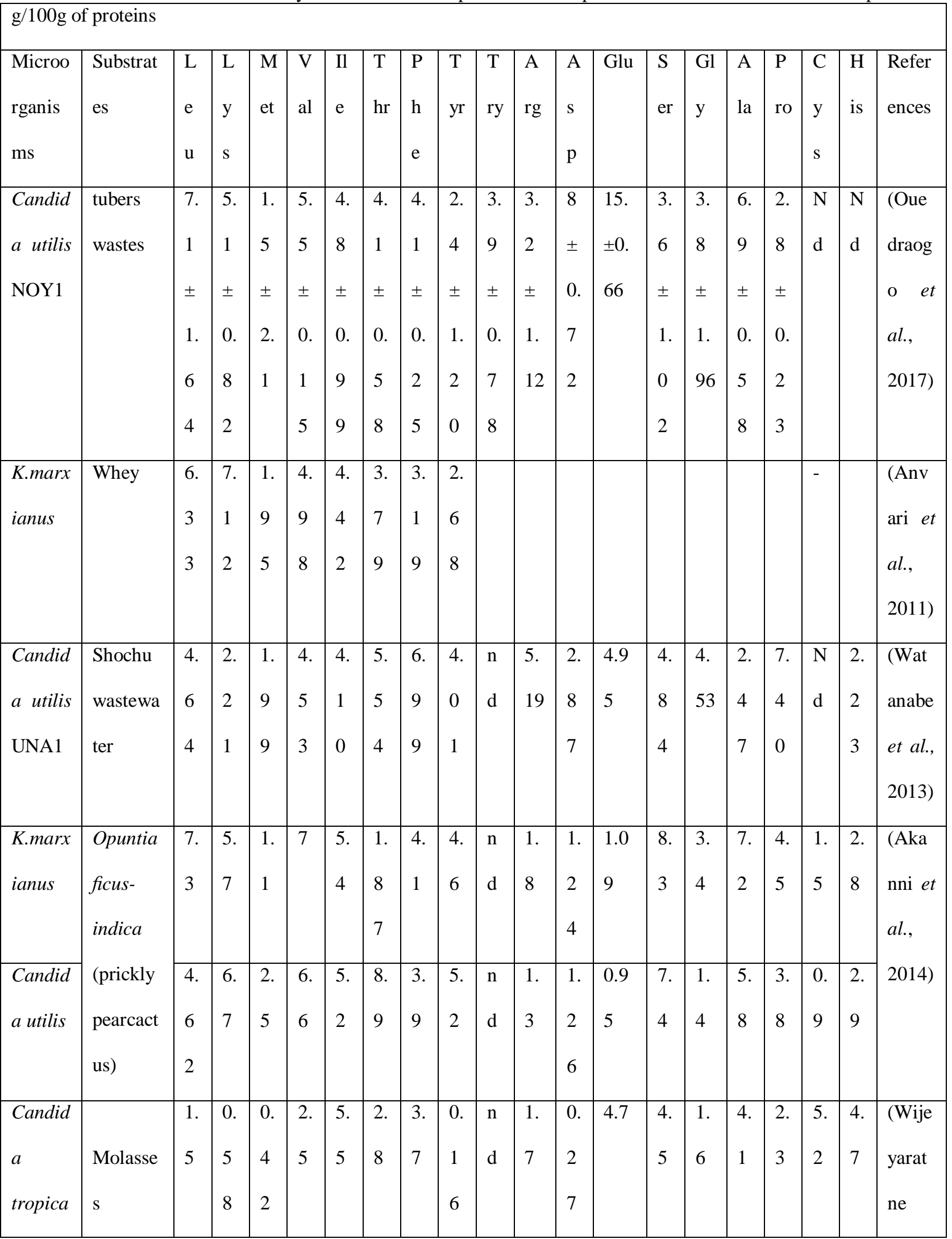




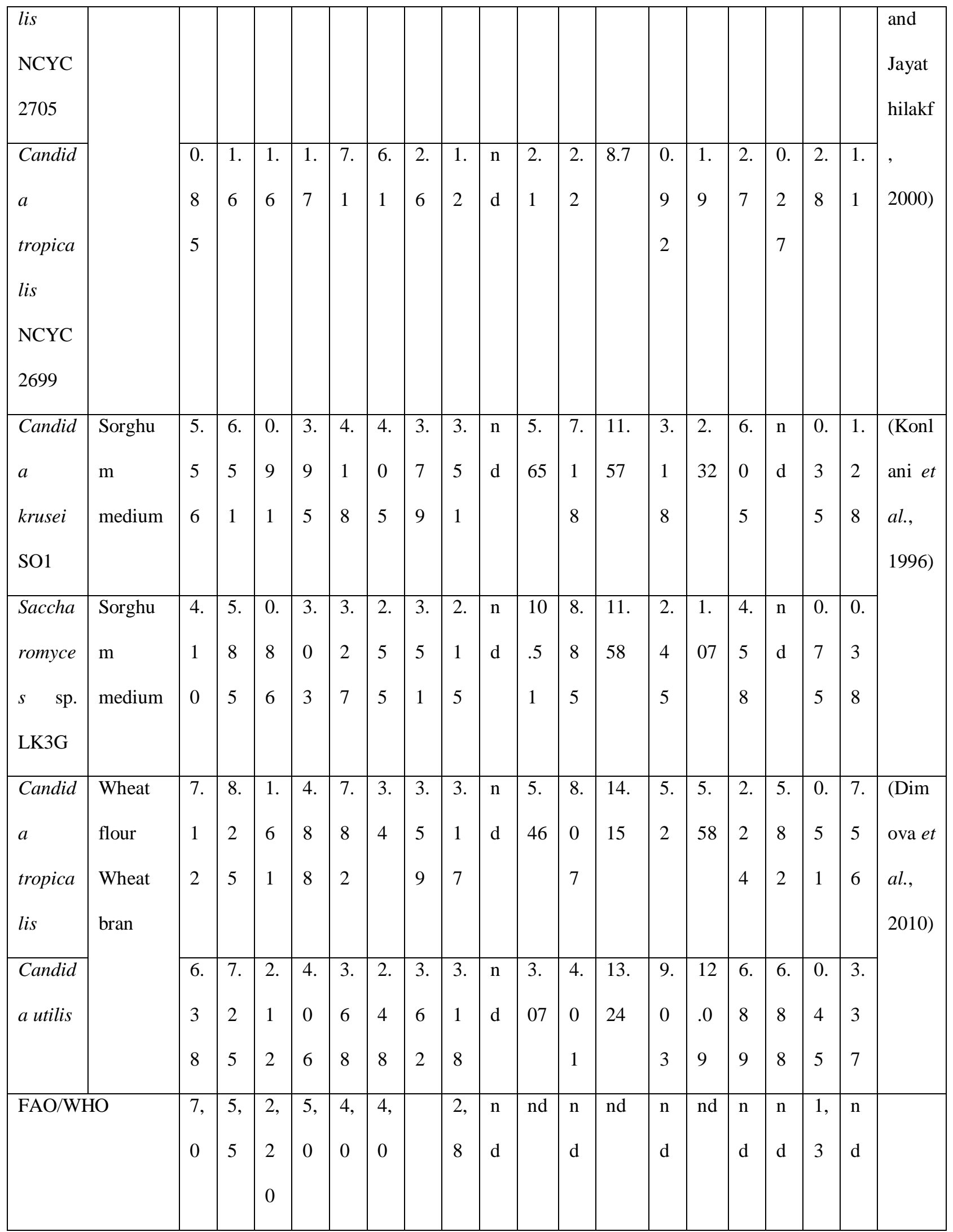




\begin{tabular}{|l|l|l|l|l|l|l|l|l|l|l|l|l|l|l|l|l|l|l|l|l|}
\hline Fish flour & 7, & 7, & 2, & 5, & 4, & 4, & 4, & 3, & 1, & 5, & $\mathrm{n}$ & $\mathrm{nd}$ & $\mathrm{n}$ & 5, & $\mathrm{n}$ & $\mathrm{n}$ & 1, & 2, & & \\
& 6 & 4 & 9 & 6 & 8 & 5 & 4 & 5 & 3 & 5 & $\mathrm{~d}$ & & $\mathrm{~d}$ & 8 & $\mathrm{~d}$ & $\mathrm{~d}$ & 0 & 3 \\
\hline Soy grains flour & 7, & 6, & 1, & 5, & 4, & 4, & 4, & 3, & 1, & 7, & $\mathrm{n}$ & $\mathrm{nd}$ & $\mathrm{n}$ & 4, & $\mathrm{n}$ & $\mathrm{n}$ & 1, & 2, & \\
& 5 & 1 & 4 & 0 & 8 & 0 & 9 & 5 & 3 & 2 & $\mathrm{~d}$ & & $\mathrm{~d}$ & 2 & $\mathrm{~d}$ & $\mathrm{~d}$ & 5 & 5 \\
\hline
\end{tabular}

There is ten (10) essential amino acids which must be present in food to give it a good nutritional value. Unfortunately, vegetable foods are poor for those amino acids comparing to animal foods. However, microorganisms present an interesting profile in amino acids. Indeed, SCP produce from yeasts contain an interesting rates of essential amino acids (tryptophan, lysine, methionine, phenylalanine, threonine, valine, leucine, isoleucine, arginine and histidine) (Dimova et al., 2010; Anvari et al., 2011; Watanabe et al., 2013). The comparison of amino acids profile of yeasts used for SCP production with soy flour and fish flour shows that yeasts present a good amino acids balance (Table 1). Because they have an interesting rate of lysine, yeasts can be used to supplement cereal foods that are poor of proteins and lysine. Added, yeasts contained a high rate of vitamin like thiamin, Riboflavin, Niacin... (Table 2). Indeed, vitamin B is the most type of vitamin found in yeast strains used for SCP production. Wijeyaratne et Jayathilak, (2000) obtained 0,231 mg/g of riboflavin and 0,178 $\mathrm{mg} / \mathrm{g}$ of thiamine with Candida tropicalis used for SCP production. Nangul and Bhatia, (2013)showed that vitamin B12 is mostly found from yeasts and bacteria, and vitamin $\mathrm{A}$ is mostly found in algae.

Table 2:-Vitamins contained in yeasts species Candida utilis and Saccharomyces cerevisiae

\begin{tabular}{|l|cc|c|}
\hline Vitamin & $\begin{array}{l}\text { Candida } \\
\text { weight })\end{array}$ & utilis $(\mathrm{mg} / 100 \quad \mathrm{~g}$ dry & $\begin{array}{l}\text { Saccharomyces cerevisiae }(\mathrm{mg} / 100 \quad \mathrm{~g} \text { dry } \\
\text { weight })\end{array}$ \\
\hline Thiamine & 0,53 & $5-36$ \\
\hline Riboflavin & 4,50 & $3,6-4,2$ \\
\hline Niacin & 41,73 & $80-100$ \\
\hline Pyridoxine & 3,34 & $2,5-10$ \\
\hline Pantothenic Acid & 3,72 & 10 \\
\hline Choline & - & - \\
\hline Folic Acid & 2,15 & $1,5-8,0$ \\
\hline Inositol & - & - \\
\hline Biotin & 0,23 & $0,5-1,8$ \\
\hline Vitamin B12 & 0 & 0 \\
\hline P-amino benzoic Acid & 1,7 & $0,9-1,0$ \\
\hline
\end{tabular}

Added to all those vitamins, amino acids and proteins, yeasts contain also a high rate of mineral salts. All of those compounds make yeasts a good source of nutriments for food and feed production.

\section{Single Cell Protein from Yeasts}

For biotransformation process, a variety of microorganism and substrate are used to produce Single Cell Proteins (SCP)(Ouedraogo et al., 2012; Ahmed et al., 2017; Somda et al., 2017). Yeast is suitable for single cell protein production because of its superior nutritional quality. The supplementation cereals with single cell proteins, especially yeast, make them as good as animal protein (Nasseri et al., 2011; Mogmenga et al., 2017). The demonstration of the absence of toxic and carcinogenic compounds originated from the substrates, biosynthesized by the microorganisms or formed during processing are important factors which will be considered before SCP using. Production of yeast SCP has certain advantages compared to plant, animal, and other microbial sources of SCP including rapid growth and accumulation of biomass, high protein content (up to 60\%), high contents of vitamins and minerals, and ability to grow on a wide variety of substrates, including various industrial complex wastes (ElNawwi and El-Kader, 1996; Somda et al., 2017). The production of value-added SCP from inexpensive substrates could help to alleviate world shortages in the food supply, particularly in developing countries. Substrates utilized have included molasses, starch, cassava, Helianthus tuberosus, whey products, sulfite waste liquor, potato wastes, brewery wastes and other waste streams from agricultural processes, food processing, and industrial processes (Nasseri et al., 2011; Suman et al., 2015; Ali et al., 2017). Due to the relatively large cell size and flocculation 
abilities of yeasts, they can be more easily harvested than bacteria from the fermentation liquor. Compared to bacteria, many types of yeast contain low quantities of nucleic acids, which can have detrimental nutritional effects.

\section{Yeast in African fermented foods}

African fermented foods are fermented foods produced with locally available ingredients, instruments and techniques. Although the production of fermented foods in Africa has deceased globally in recent years due to the spread of mass-produced of industrial food, fermented foods are still popular in sub-Saharan Africa (Kubo and Kilasara, 2016). In this regions, fermented food take place on socially, economically, and nutritionally important roles. Popular fermented food products in Africa include fermented milks, fermented cereals, fermented leaves, sour porridges, and alcoholic and non-alcoholic beverages and the fermentation improves the organoleptic properties of foods, their acceptability, and their nutritional value. Microorganisms responsible for those fermentation can be indigenous microorganisms present on substrates, or they can be added as starter cultures after cooking or preparing the food or beverage (Sarkar et al., 2002; Oguntoyinbo et al., 2011; Mogmenga et al., 2017). Yeats strains have been isolated and identified in several types of fermented foods.

\section{Cereal fermented food}

Koko and Kenkey in Ghana, Ben-saalga, Massa and Gappal in Burkina Faso, Kisra and Hussuwa in Sudan, Gowé and Mawè in Benin Republic and Togo, Ogi and Kunu-zaki in Nigeria, Mbege in Tanzania... are cereal fermented food produced in some countries of Africa (Table 3). Fermented cereal foods play an important socio-economic role in developing countries as well as making a major contribution to the protein requirements of natural populations (Achi and Ukwuru, 2015). Mostly, maize (Zea mays), Sorghum (Sorghum bicolor), millet (Peninsetum americanum) are used as raw materials in the production of fermented foods Africa (Table 3).

Table 3:-Yeasts involved in cereal fermented foods in Africa

\begin{tabular}{|c|c|c|c|c|}
\hline Product & $\begin{array}{l}\text { Raw material/ } \\
\text { Substrate }\end{array}$ & Microorganisms & Country & References \\
\hline Busa & $\begin{array}{l}\text { Maize, } \\
\text { sorghum, millet }\end{array}$ & $\begin{array}{ll}\text { Saccharomyces } & \text { cerevisiae, } \\
\text { Schizosacchromyces pombe, } & \end{array}$ & $\begin{array}{l}\text { East Africa, } \\
\text { Kenya }\end{array}$ & $\begin{array}{l}\text { Blandino et al. } \\
\text { (2003) }\end{array}$ \\
\hline $\begin{array}{l}\text { Enjera/ } \\
\text { Injera }\end{array}$ & Tef flour, wheat & $\begin{array}{l}\text { Ped. cerevisiae, Sacch. cerevisiae, Cand. } \\
\text { glabrata }\end{array}$ & Ethiopia & $\begin{array}{l}\text { Olasupo et } \\
(2010)\end{array}$ \\
\hline Gowé & Maize & $\begin{array}{l}\text { Candida tropicalis, Candida krusei, } \\
\text { Kluyveromyces marxianus }\end{array}$ & Benin & $\begin{array}{l}\text { Vieira-Dalodé et } \\
\text { al. (2007) } \\
\text { Greppi et al. } \\
(2013)\end{array}$ \\
\hline $\begin{array}{l}\text { Kunu-zaki } \\
\text { Kenkey }\end{array}$ & $\begin{array}{l}\text { Maize, } \\
\text { sorghum, millet }\end{array}$ & $\begin{array}{l}\text { Candida mycoderma, Saccharomyces } \\
\text { cerevisiae, Rhodotorula sp., }\end{array}$ & Nigeria & $\begin{array}{l}\text { Olasupo et al. } \\
\text { (2010) } \\
\text { Oguntoyinbo et al. } \\
(2011)\end{array}$ \\
\hline Kisra & Sorghum & Candida intermedia, Deb. hansenii, & Sudan & $\begin{array}{l}\text { Hamad et al. } \\
(1997)\end{array}$ \\
\hline Koko & Maize & $\begin{array}{lll}\begin{array}{l}\text { Saccharomyces } \\
\text { mycoderma }\end{array} & \text { cerevisiae, Candida } \\
\end{array}$ & Ghana & $\begin{array}{l}\text { Blandino et al. } \\
(2003)\end{array}$ \\
\hline Mawè & Maize & $\begin{array}{l}\text { Candida glabrata, Saccharomyces } \\
\text { cerevisiae, Kluyveromyces marxianus, } \\
\text { Clavispora lusitaniae }\end{array}$ & Benin, Togo & $\begin{array}{lll}\text { Greppi } & \text { et } & \text { al. } \\
(2013 a) & & \end{array}$ \\
\hline Mbege & $\begin{array}{l}\text { Maize, } \\
\text { sorghum, millet }\end{array}$ & $\begin{array}{l}\text { Saccharomyces cerevisiae, } \\
\text { Schizosaccharomyces pombe }\end{array}$ & Tanzania & Franz et al. (2014) \\
\hline Ogi & $\begin{array}{l}\text { Maize, } \\
\text { sorghum, millet }\end{array}$ & 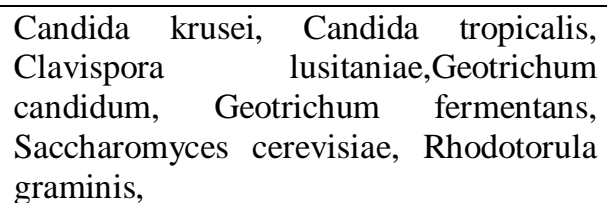 & Nigeria & $\begin{array}{llr}\text { Omemu } & \text { et } & \text { al., } \\
2007 & & \\
\text { Greppi } & \text { et } & \text { al. } \\
(2013 b) & & \end{array}$ \\
\hline Pito & Maize, sorghum & Saccharomyces cerevisiae, & West Africa & Sawadogo-Lingani \\
\hline
\end{tabular}




\begin{tabular}{|l|l|l|l|l|}
\hline Dolo & tropicalis & & et al. (2010) \\
\hline Togwa & $\begin{array}{l}\text { Cassava, } \\
\text { maize, } \\
\text { sorghum, millet }\end{array}$ & $\begin{array}{l}\text { Issatchenkia orientalis, Saccharomyces } \\
\text { cerevisiae, Candida pelliculosa and } \\
\text { Candida tropicalis }\end{array}$ & $\begin{array}{l}\text { Tanzania } \\
(2003)\end{array}$ \\
\hline
\end{tabular}

Cereal grains constitute a major source of dietary nutrients all over Africa. Maize, millet, rice and sorghum are popular substrates used for the production of many fermented foods (Table 3). Although cereals are deficient in some basic components like essential amino acids, proteins, fermentation may be the most simple and economical way of improving their nutritional value, sensory properties, and functional qualities. The fermentation of cereals enhances the availability of nutritional elements in cereal grains (Laurent-Babot and Guyot, 2017).

The most yeast involved in Africa fermented food is Saccharomyces cerevisiae. Indeed, Saccharomyces cerevisiae is always isolated in fermented food and it is also the most representative yeast in fermented foods. The role of yeast in fermented foods production is very important and various. Indeed, the nutritional quality of cereals and the sensorial properties of their products are sometimes inferior or poor in comparison with milk and milk products. With the large method that are used to improve the nutritional qualities of cereals, natural fermentation of cereals leads to a decrease in the level of carbohydrates as well as some non-digestible poly and oligosaccharides. Certain amino acids may be synthesised and the availability of B group vitamins may be improved (Achi and Ukwuru, 2015; Olanbiwoninu et al., 2017). Fermentation also provides optimum $\mathrm{pH}$ conditions for enzymatic degradation of antinutritional factor such as phytate which is present in cereals in the form of complexes with polivalent cations such as iron, zinc, calcium, magnesium and proteins. Added to Saccharomyces cerevisiae, Issatchenkia orientalis, Candida pelliculosa, Candida utilis, Candida tropicalis and Rhodotorula muciloginosa... were also isolated from African fermented food.

\section{Fermented milk product}

Fermented milk is an important part of traditional diet in African countries. Many traditional fermented milk products were made in Africa including Nunu in Ghana, Amasi in South Africa and Zimbabwe, Laban rayeb in Egypt, Leben/Lben in North, East and Central Africa, Mursik in Kenya, Gappal in Burkina Faso presented in (Table 4).

Table 4:-Yeasts isolated from some fermented milk products in Africa

\begin{tabular}{|c|c|c|c|c|}
\hline Product & Substrate & Microorganisms & Country & References \\
\hline $\begin{array}{l}\text { Amabere } \\
\text { amaruranu }\end{array}$ & $\begin{array}{l}\text { cow } \\
\text { milk }\end{array}$ & $\begin{array}{l}\text { Saccharomyces cerevisiae, Trichosporon } \\
\text { mucoides, Candida famata, Candida } \\
\text { albicans }\end{array}$ & Kenya & $\begin{array}{l}\text { Nyambane et } \\
\text { al. (2014) }\end{array}$ \\
\hline Kefir & Milk & $\begin{array}{l}\text { Candida kefir, Candida holmii, Candida } \\
\text { lipolytica, Zygosaccharomyces spp. }\end{array}$ & South Africa & $\begin{array}{l}\text { Witthuhn et } \\
\text { al. (2004) }\end{array}$ \\
\hline Leben / Lben & $\begin{array}{l}\text { Cow or goat } \\
\text { milk }\end{array}$ & $\begin{array}{l}\text { Candida krusei, Candida tropicalis, Candida } \\
\text { lusitaniae, Kluyveromyces lactis, } \\
\text { Saccharomyces cerevisiae }\end{array}$ & $\begin{array}{l}\text { North, East } \\
\text { Central } \\
\text { Africa }\end{array}$ & $\begin{array}{l}\text { Fguiri et al. } \\
\text { (2012); } \\
\text { Samet-Bali et } \\
\text { al. (2017) }\end{array}$ \\
\hline Mursik & Milk & $\begin{array}{l}\text { Candida sphaerica, Candida kefyr, } \\
\text { Saccharomyces fermentati }\end{array}$ & Kenya & $\begin{array}{l}\text { Nieminen et } \\
\text { al. (2013) }\end{array}$ \\
\hline Nunu & Raw cow milk & $\begin{array}{l}\text { Candida parapsilosis, C. rugosa, C. } \\
\text { tropicalis, Galactomyces geotrichum, Pichia } \\
\text { kudriavzevii, Sacch. cerevisiae }\end{array}$ & Ghana & $\begin{array}{l}\text { Akabanda et } \\
\text { al. (2014) }\end{array}$ \\
\hline Gappal & Cow milk & Not identified & Burkina Faso & $\begin{array}{l}\text { Tankoano et } \\
\text { al. (2017) }\end{array}$ \\
\hline Sethemi & Cow milk & 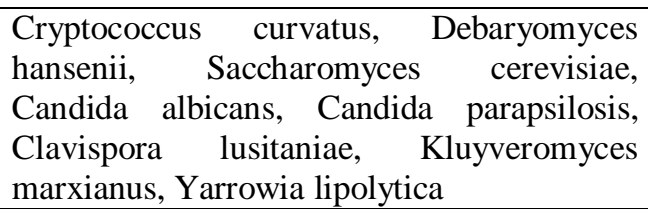 & South Africa & $\begin{array}{l}\text { Kebede et al. } \\
(2007)\end{array}$ \\
\hline Suusac & Camel milk & $\begin{array}{l}\text { Candida krusei, Geotrichum penicillatum } \\
\text { Rhodotorula mucilaginosa }\end{array}$ & Kenya & $\begin{array}{l}\text { Lore et al., } \\
2005)\end{array}$ \\
\hline
\end{tabular}


Milk in Africa has a strong connection to pastoralists, who have a long tradition in dairy production (Jans et al., 2017). Milk products are usually consumed and traded either as raw milk or traditional fermented dairy products. For pastoralists, milk is an important source of micronutrients, vitamins and energy-containing fat. Milk contributes $10 \%$ of the energy and more than $50 \%$ of the micronutrients, including vitamins A, B12 and C, to their diets (Iannotti and Lesorogol, 2014) In Africa countries, milk is also mixed with cereals or other plant materials before fermentation to yield products such as Gappal in Burkina Faso (Tankoano et al., 2017). However, cow milk, camel milk and goat milk are mostly used for fermented dairy products production in Africa such as Nunu (cow; Ghana), Sethemi (South Africa), Suusac (camel; Kenya), Leben/Lben (cow or goat; North, East and Center Africa), Gappal (cow; Burkina Faso), Mabisi (cow; Zimbabwe) (Table 4). During this process of fermentation, several types of microorganisms are involved including yeasts.

The role of yeasts is often underestimated in fermented dairy products. But, they contribute significantly to product development during fermentation processes through lactose and galactose metabolism, proteolysis, lipolysis and enzymatic degradation, which contributes to flavor development (Quigley et al., 2013). Several types of yeasts such as Candida spp., Cryptococcus spp., Debaryomyces spp., Geotrichum spp., Issatchenkia spp., Kluyveromyces spp. and Saccharomyces cerevisiae were isolated from fermented dairy products in Africa (Table 4). The presence of yeasts in fermented dairy products suggests that they contribute to product development. However, several studies on yeasts involving in fermented dairy products in Africa are mostly an enumeration of total yeasts in these products (Savadogo et al., 2004; Tankoano et al., 2017), but few reports have made a detailed study of the species present.

\section{Alcoholic fermented beverages}

Yeasts are involved in the production of Africa traditional fermented alcoholic beverages. In several types of alcoholic beverages, yeasts were main microorganisms isolated and Saccharomyces cerevisiae was the main species (Douradinha et al., 2014; Lyumugabe et al., 2014; Lara-Hidalgo et al., 2017; Mogmenga et al., 2017). Yeasts in alcoholic beverages production transform the sugars present in the substrate to ethanol and other metabolites. It also produces a number of volatile molecules, such as aldehydes, esters, organic acids, higher alcohols and carbonyl compounds responsible for sensory characteristics of alcoholic beverages (Bhalla, 2017). Several types of raw material have been used in African countries for alcoholic beverages production but Sorghum bicolor L, Setaria italic and Zea mays are the most cereals used. Tchoukoutou in Benin, dolo in Burkina-Faso, pito in Ghana, Tchapalo in Ivory Coast, burukutu or otika in Nigeria ikigage in Rwanda, bili bili in Chad... are the name of traditional alcoholic fermented beverages in some countries of Africa (Kayodé et al., 2012; Lyumugabe et al., 2014; Mogmenga et al., 2017). All these alcoholic beverages play an important role in African societies because they are used in some ceremonies like funeral, wedding and baptism, and the selling of the beverage constitutes an important source of money for the sellers who are generally women. Even if Saccharomyces cerevisiae is consider like the principal microorganism during alcoholic beverages production, others species of yeasts were also isolated and identified. Indeed, Candida utilis, Rhodotorula muciloginosa, Sporobolomyces odoratus, Candida pseudorhagii, Candida heliconiae, Schizosaccharomyces octosporus, Schizosaccharomyces pombe, Zygosaccharomyces rouxii, were identified from chakpalo and burukutu (Benin) (Djegui et al., 2014; Djêgui et al., 2015); dolo (Burkina Faso), (Konlani et al., 1996; Glover et al., 2009), burukutu (Ghana)(Atter et al., 2014),Ikigage (Rwanda)(Lyumugabe et al., 2014)... were isolated and identified from African traditional alcoholic beverages.

\section{Modern Applications of Yeasts}

In addition to traditional applications of yeasts in several food fermentations such as alcoholic beverages, bakery products, cheese, sausages, and other fermented foods, several yeasts genera and species are industrially or have potentiality in biotechnology (Tamang et al., 2016; Mogmenga et al., 2017). Nowadays, yeasts can be used to produce fuel ethanol, single cell protein (SCP), feeds and fodder, industrial enzymes, and small molecular weight metabolites. Yeasts species like Pichia pastoris, Saccharomyces cerevisiae, Hansenula polymorpha, and certain other yeast species have been developed the heterologous production of enzymes and proteins, including protein pharmaceuticals (Steensels et al., 2014; Türker, 2014; Awan et al., 2017). Saccharomyces cerevisiae is increasingly used as hosts for expression of protein biocatalysts and multi-enzyme pathways for the synthesis of fine chemicals and small molecular weight compounds of medicinal and nutritional importance. Yeasts have important roles in agriculture as agents of biocontrol, bioremediation, and as indicators of environmental quality (Hatoum et al., 2012). Yeasts species belong to ascomycetous (Saccharomyces cerevisiae, Schizosaccharomyces pombe, Kluyveromyces lactis, Kluyveromyces marxianus, Schwanniomyces occidentalis, Debaryomyces hansenii, Komagataella pastoris...) and to basidiomycetous (Rhodotorula spp., Rhodosporidium spp., Trichosporon spp., Xanthophyllomyces 
dendrorhous, Cryptococcus spp., Phaffia rhodozyma...) were used in biotechnologies processes for interesting compounds production.

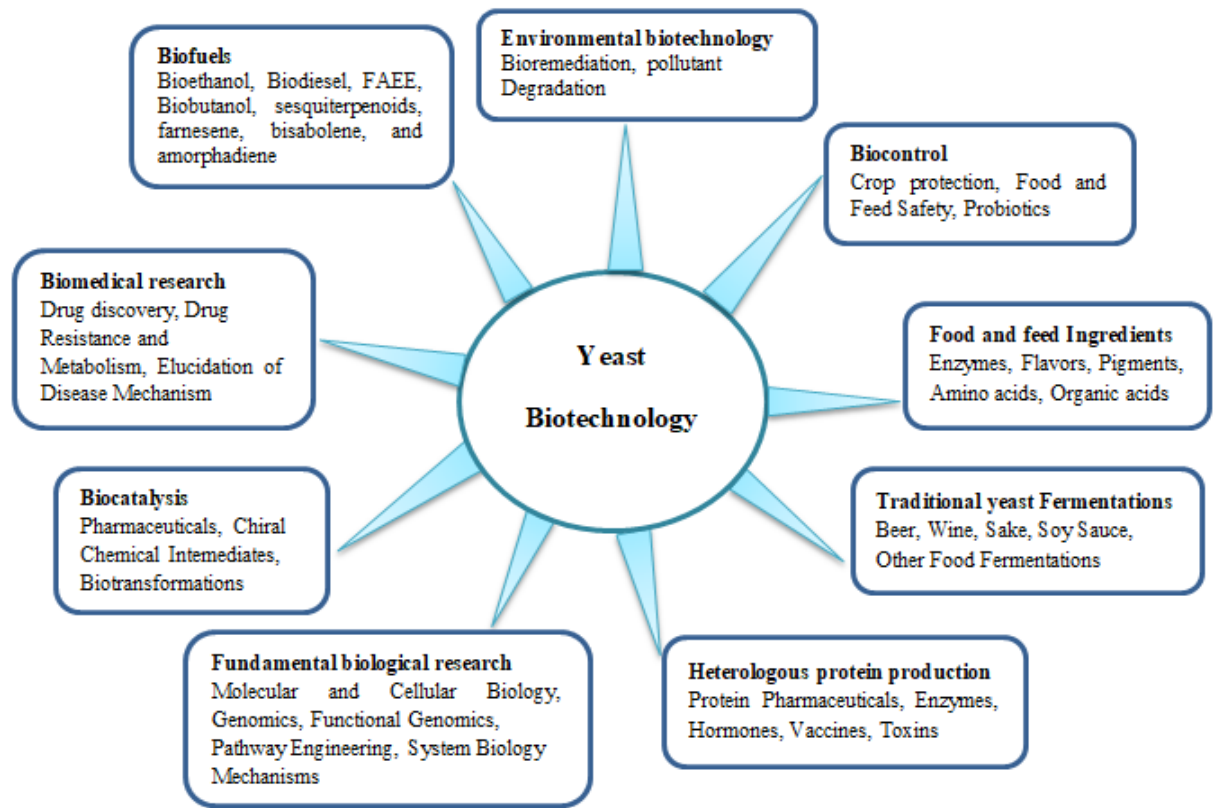

Figure 1:-Modern Applications of Yeasts (adapted from Türker 2014)

\section{Production of Enzymes}

Enzymes have numerous applications and biotechnological potential for various industries including chemicals, fuel, food, brewery and wine, animal feed, textile and laundry, pulp and paper and agriculture (Graf et al., 2009; Johnson, 2013; Türker, 2014).The food industry is the largest user of bulk enzymes. The bulk enzyme market is dominated by enzymes produced by bacteria and filamentous fungi cultivated in submerged culture, particularly Bacillus and Aspergillus species (Olempska-Beer et al., 2006). Only a limited number of yeast enzymes are currently used as bulk enzymes in commodity processes, as shown in (Table 5).

Table 5:-Industrial Enzymes from Yeasts (Fonseca et al., 2008; Johnson and Echavarri-Erasun, 2011)

\begin{tabular}{|l|l|l|}
\hline Enzyme & Yeast & Industry \\
\hline Chymosin & $\begin{array}{l}\text { Kluyveromyces spp. } \\
\text { Saccharomyces cerevisiae }\end{array}$ & Food processing \\
\hline$\alpha$-Galactosidase & Saccharomyces spp & Feed applications \\
\hline L-Glutaminase & Zygosaccharomycesrouxii & Therapeutic, Analytical \\
\hline Inulinases & $\begin{array}{l}\text { Candida spp. } \\
\text { Kluyveromycesmarxianus }\end{array}$ & Food applications \\
\hline Invertase & Saccharomyces cerevisiae & Food applications \\
\hline Lactase & $\begin{array}{l}\text { Candida pseudotropicalis } \\
\text { Kluyveromycesspp. }\end{array}$ & Food processing \\
\hline Lipase & $\begin{array}{l}\text { Candida rugosa } \\
\text { Pseudozymaantarctica } \\
\text { Geotrichumcandidum } \\
\text { Trichosporonfermentum } \\
\text { Yarrowialipolytica }\end{array}$ & $\begin{array}{l}\text { Food processing } \\
\text { Flavors, Wastewater } \\
\text { Degreasing, Bioremediation } \\
\text { Therapeutic, Detergent }\end{array}$ \\
\hline $\begin{array}{l}\text { L-Phenylalanine } \\
\text { ammonialyase }\end{array}$ & $\begin{array}{l}\text { Rhodotorula spp. } \\
\text { Rhodosporidium spp. }\end{array}$ & Pharmaceutical \\
\hline $\begin{array}{l}\text { Phenylalanine } \\
\text { dehydrogenase }\end{array}$ & Candida boidinii & Pharmaceutical \\
\hline Phytase & Ogataea polymorpha & Feed, Nutrition \\
\hline
\end{tabular}


However, several types of enzymes produce by yeasts have found application in the production of high-value specialized fine chemicals and for biotransformation of pharmaceutical intermediates (Badia et al., 2012; Martinez et al., 2012). Currently, industrial recombinant enzymes like Chymosin, Glycolate oxidase and Phytase are produced as heterologous proteins by Kluyveromyces lactis and Komagataella pastoris (Johnson and Echavarri-Erasun, 2011). Industrial recombinant enzymes and those close to commercialization produced by yeasts are presented in (Table 5). Yeasts are desirable hosts of enzymes for food uses because of their lack of production of toxic secondary metabolites (Olempska-Beer et al., 2006).

\section{Medical application}

The yeasts constitute a large group of microorganisms characterized by the ability to grow and survive in different and stressful conditions and then to colonize a wide range of environmental and human ecosystems. The medical applications of yeasts include their using as probiotics and the production of antibodies and viral antigens production. Several studies showed that yeasts can be used against other microorganisms (Mcfarland, 2010, 2015; Hatoum et al., 2012). The competitive traits against other microorganisms have attracted increasing attention from scientists, who proposed their successful application as bioprotective agents in the agricultural, food and medical sectors (Hatoum et al., 2012; Türker, 2014).

According to Atter et al. (2014), during the fermentation yeasts produce the substances which inhibit and neutralize total coliform growing. But the antagonism of microorganisms by yeasts has been attributed primarily to (i) competition for nutrients, (ii) $\mathrm{pH}$ changes in the medium as a result of growth-coupled ion exchange or organic acid production, (iii) production of high concentrations of ethanol, (iv) secretion of antibacterial compounds and release of antimicrobial compounds such as killer toxins or "mycocins" (Suzuki et al., 2001). Added, yeasts are used Saccharomyces boulardii in combination with antibiotics has been shown effective for treating Clostridium difficile associated diarrhea and colitis (Mcfarland, 2010, 2015; Badia et al., 2012; Martinez et al., 2012). Fakruddin et al. (2017) showed that Saccharomyces cerevisiae IFST 062013 could be used as probiotics in human food. Also, Badia et al. (2012) showed that Saccharomyces cerevisiae var. boulardii with $\beta$-galactomannan inhibits Salmonellainduced proinflammatory profiles in porcine ileum intestinal epithelial cells but may promote monocyte-derived dendritic cells activation. Several studies on yeasts utilization to produce virus-like particles were been done (Evaldas et al., 2011; Rodríguez-Limas et al., 2011; Vanz et al., 2012; Tomo et al., 2013). These virus-like particles (VLP) have an increasing range of applications including vaccination, drug delivery, diagnostics, gene therapy and nanotechnology (Willaert, 2017).Saccharomyces cerevisiae and Pichia pastoris GS115 were used to produce viruslike particles (Evaldas et al., 2011; Rodríguez-Limas et al., 2011; Vanz et al., 2012; Tomo et al., 2013). But mainly, the therapeutic proteins produced in yeast are specifically from Saccharomyces cerevisiae and include hormones (insulin, insulin analogues, non-glycosylated human growth hormone somatotropin, glucagon), vaccines (hepatitis B virus surface antigen) (Baeshen et al., 2014).

\section{Agricultural Applications}

Microorganisms utilization to prevent postharvest losses of stored fruits, vegetables and grains due to decay by fungal pathogens has been done, and in fact, addressing this problem is receiving increasing importance as worldwide demand for food increases. Chemical fungicides utilization to avoid injury postharvest decay of fruits modified has damages on fruits quality and on the consumer health. Postharvest losses of stored fruits can be attribute by several fungal species belonging to Alternaria, Aspergillus, Botrytis, Fusarium, Geotrichum, Gloeosporium, Mucor, Monilinia, Penicillium, Rhizopus and other genera (Pimenta et al., 2009). Chemical pesticides and fungicides are used to control fruits postharvest diseases. But the main problem of chemical pesticides and fungicides are related to environmental pollution and public health concerns (Pimenta et al., 2009).

The utilization of microbial antagonists like yeasts, fungi and bacteria like alternative approaches of to prevent fruits postharvest loses has been demonstrated to be quite promising and gained increased attention. Yeasts are the majority of microorganisms studied for their potential use as postharvest biocontrol agents (Table 6). Mainly, the fact that many of these microorganisms are considered as able to prevent fruits postharvest loses should include a rapid growth rate in fruit wounds, the effective utilization of the nutrients present in the wound, and the capability to survive and develop at the infection site better than the pathogen. Also, this should occur at a low temperature, acidic $\mathrm{pH}$, and condition of osmotic stress, resistance to desiccation and tolerance to chemicals. The yeast in postharvest biocontrol formulations apparently presents advantages over other organisms: easy to cultivate, fast growing and readily found in a variety of substrates and conditions (Konlani et al., 1996; Somda et al., 2011; Ouédraogo et al., 2012). They can be used as biocontrol agents (Johnson, 2013). This research has mainly focused 
on their use for managing postharvest diseases, mainly of fruit; however, this application represents only a small portion of the complete spectrum of plant disease management (Schisler et al., 2011; Türker, 2014).

Table 6:-Examples of yeast antagonists applied preharvest to reduce postharvest pathogens (Schisler et al., 2010)

\begin{tabular}{|l|l|l|}
\hline Yeast/Yeast-like & Fungus Disease & Assessment Utilized \\
\hline $\begin{array}{l}\text { Aureobasidium pullulans } \\
\text { Aureobasidium pullulansand }\end{array}$ & $\begin{array}{l}\text { Various postharvest rots } \\
\text { Gray mold, blue mold, bull's eye rot }\end{array}$ & $\begin{array}{l}\text { Cherry fruit } \\
\text { Apple fruit }\end{array}$ \\
\hline Rhodotorula glutinis & Blue mold & Apple fruit \\
\hline Candida sake & Gray mold & Strawberry fruit \\
\hline $\begin{array}{l}\text { Cryptococcus albidus } \\
\text { Cystofilobasidium infirmominatum }\end{array}$ & $\begin{array}{l}\text { Blue and gray mold, side rot } \\
\text { Various postharvest rots }\end{array}$ & $\begin{array}{l}\text { Pear fruit } \\
\text { Cherry fruit }\end{array}$ \\
\hline $\begin{array}{l}\text { Cryptococcus laurentii, and } \\
\text { Rhodotorula glutinis }\end{array}$ & Gray mold, other postharvest rots & Table grape fruit \\
\hline $\begin{array}{l}\text { Cryptococcus laurentii } \\
\text { Metschnikowia fructicola } \\
\text { Rhodotorula minuta }\end{array}$ & Anthracnose & Mango fruit \\
\hline
\end{tabular}

\section{Environmental Applications}

Yeasts have important roles in the biotransformation and degradation of pollutants and xenobiotics. Cryptococcus and Trichosporon species are capable of degrading polysaccharides, phenolic compounds, complex organic acids, and C2 hydrocarbons. Strains of Pseudozyma have been reported to degrade plastics and related compounds (Seo et al., 2007; Pimenta et al., 2009). Several types organic wastes from industrial, housekeep or municipal contain fermentable sugar which could be used to produce value-added products like enzymes, SCP, bioethanol, organic acids, oligosaccharides, esters, etc. by yeasts (Table 7).

Tableau 7:-Examples of treatment/biotransformation of recalcitrant chemicals, pollutants, organic wastes and xenobiotics by yeast (Johnson and Echavarri-Erasun, 2011)

\begin{tabular}{|l|l|}
\hline Waste/Compounds & Yeast \\
\hline $\begin{array}{l}\text { Phthalic Acid Esters phenol, acetophenone, acetone, } \\
\text { amethylstyrene, benzoic acid, dimethyl phenyl carbinol, } \\
\text { methanol and isopropylbenzene }\end{array}$ & $\begin{array}{l}\text { Saccharomyces cerevisiae } \\
\text { Trichosporon cutaneum }\end{array}$ \\
\hline Olive mill wastewater & $\begin{array}{l}\text { Candida rugosa, Candida cylindracea and } \\
\text { Yarrowia lipolytica }\end{array}$ \\
\hline Decolorization of molasses wastewater & Issatchenkiaorientalis \\
\hline Phenol & $\begin{array}{l}\text { Rhodotorula creatinivora } \\
\text { Cryptococcus terreus }\end{array}$ \\
\hline Plastic waste & Pseudozyma jejuensis \\
\hline Phosphorus removal & Hansenula anomala \\
\hline Nitrate assimilation & Hansenula polymorpha \\
\hline Removal of lactose/other sugars from wastewater & Kluyveromyces marxianus \\
\hline $\begin{array}{l}\text { Organics wastes/sorghum hydrolysat, molasses, tubercules, } \\
\text { apples, oranges, bananas... }\end{array}$ & $\begin{array}{l}\text { Saccharomyces cerevisiae, Candida utilis, } \\
\text { Candida tropicalis, Candida kruseis }\end{array}$ \\
\hline
\end{tabular}

Several types of basidiomycetous yeasts including species of Cryptococcus, Rhodotorula, and Trichosporon were shown to degrade starch, pullulan, dextran, xylan, polygalacturonate, galactomannan, and tannic acid as sole carbon source (Fonseca et al., 2008; Johnson 2013). They were unable to grow on cellulose, chitin, arabinogalactan, and xanthan gum. Also, they grow on phenolic compounds. These results indicate that basidiomycetous yeasts are involved in the natural biodegradation of biomass and may have potential for remediation of various industrial waste streams (Johnson 2013).

Yeast systems have also been developed for the sensing and accumulation of various ecotoxicants such as heavy metals. Xanthophyllomyces dendrorhous, Trichosporon spp., Saccharomyces cerevisiae and Phaffia rhodozyma have been reported to degrade ochratoxin, patulin, a potent mycotoxin (Hatoum et al., 2012). The ability of yeasts to degrade mycotoxins has important health implications (Schisler et al., 2011). Industrial wastes biotransformation is 
not only to produce value-added products, but it is also the amount to protect environment against pollution and prevent climate change.

\section{New developments in efficient biofuel and organic acids production by yeasts}

Energy crisis is a growing global concern nowadays because of the dependence on petroleum-based fossil fuel which is exhausted very fast to meet the continuously increasing demands. Biofuels could be an alternative solution to energy security, rising prices of petroleum based fuels and for reduction in greenhouse gas emissions (Hull et al., 2014; Singhania et al., 2014). Biofuel includes solid, liquid and gas and the major biofuels encompass bio-ethanol, biodiesel, biogas, bio-methanol, bio-syngas $\left(\mathrm{CO}+\mathrm{H}_{2}\right)$, bio-oil, bio-char, bio-hydrogen, Fischer-Tropsch liquids petroleum and vegetable oil... (Gupta and Prakash, 2015).

Lignocellulosic biomass like sugar cane wastes provides a promising and renewable resource for sustainable biofuel production. But several types of agro-residues have been used to produce bio-ethanol such as rice-straw, wheat straw, sugarcane bagasse, sugarcane molasses, mangoes residues, soft bamboo, bamboo processing wastes and all are considered as abundantly available feed stocks (Abubaker et al., 2012; Singhania et al., 2014; Gupta et al., 2015; Scoma et al., 2017). And also several types of yeasts can be used to produce bio-ethanol, but the most important is Saccharomyces cerevisiae (Singh et al., 2007; Hull et al., 2014; Zabed et al., 2014; Willaert, 2017).

Organics acids such as citric acid, propionic acid, butyric acid, itaconic acid...can be used in food process, pharmaceutical, cosmetic, like detergent... (Meena et al., 2010; Ilmén et al., 2013; Guc and Erkmen, 2017). Organic acids production through microorganisms like yeasts is an important improvement in biotechnology process and establishes an ecological advantage. Indeed, yeasts can assimilate several types of raw carbon matter and produce organic acids through biotransformation process. Citric acid production attempts from industrial wastes have been realized by Yalcin et al. (2010), Pohnerkar and Desai (2014) and Guc and Erkmen (2017) with Aspergillus niger. Also, Yarrowia lipolytica has been used for the industrial production of organic acids including $\alpha$-ketoglutaric, pyruvic, citric and isocitric acids, which are used in food products (Sauer et al., 2008; Liu et al., 2014). The ability of Yarrowia lipolytica and certain Candida spp. to form high quantities of organic acids from various substrates, such as sucrose and glycerol, has seen renewed interest. Other yeast species, including Candida glabrata, have been used industrially for the production of pyruvic acid. Several yeasts have attracted industrial interest for production of primary chemicals such as itaconic, malic, gluconic, brassylic, sebacic, and fumaric acids (Walker 2011; Meena et al., 2010; Ilmén et al., 2013).

Others compound can be produced by yeasts (amino acids, vitamins). (Wijeyaratne and Jayathilakf, 2000) found that

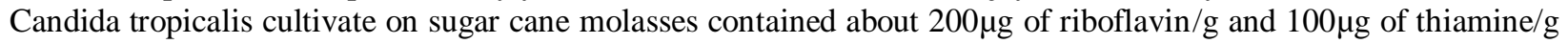
of dried cells which is adequate to fulfill the daily requirement. (Watanabe et al., 2013; Akanni et al., 2014; Ahmed et al., 2017; Ouedraogo et al., 2017) showed that yeasts can be used to produce amino acids including essential amino acids (lysine, methionine, phenylalanine and proline). Currently, yeast nanobiotechnology is a recent field which interest nanobiotechnologists, who are used nanotechniques to manipulate and analyse yeast cells and cell constituents at the nanoscale (Willaert et al., 2016; Willaert, 2017).

\section{Impact of optimal Yeast use for developing countries}

Historically, traditional fermented foods have benefit effects on human health. The traditional fermented foods and beverages in Africa have social, religious, cultural and nutritional importance. Yeasts utilization as sources of food ingredients and additives, such as flavors, colours, antioxidants and vitamins could allow in malnutrition fighting in developing countries (Kayodé et al., 2012; Douradinha et al., 2014; Hull et al., 2014; Bhalla, 2017). Also, S. cerevisiae var. boulardii, has been successfully used over the last 20 years as an oral, biotherapeutic agent to treat diarrhea and other gastrointestinal diseases at humans (Czerucka et al., 2007). The last decade has recorded few reports showing probiotic properties of yeast strains isolated from African traditional fermented foods (Kayodé et al., 2012; Bhalla, 2017). Large-scale utilization of yeasts in biotechnology processes could contribute greatly to the development of developing countries especially for African countries. She could allow African countries to improve their medical, environmental, economical, agricultural and social sectors. Economically, biotechnology processes used in industrial wastes biotransformation is a great advantage in environment protection and value-added products production. In African countries, most of industrial residues are thrown in a nature and constitute pollution source of environment. Several studies on bioconversion processes using yeasts like Saccharomyces cerevisiae, Candida utilis, Candida tropicalis, Rhodotorula muciloginosa... to produce value-added products from industry residues have been 
realized. The utilization of yeasts for pharmaceutics products expression, enzymes production and virus-like particles (VLP) production for medical sector application could allow African countries to improve their medicine.

\section{Conclusion:-}

Yeasts are interesting microorganisms and more of them are used in traditional food fermentation. Although considerable progress has been made in isolation, identification and characterization of yeast from African traditional fermented foods and beverages, continued research in these fields will lead to develop novel fermented products based on the exploitation of new and genetically modified strains of yeasts of fermented food origin. Nowadays, the number of yeast species identified and their biotechnological potential are accelerating. Their involvement and importance in biotechnological products production is increasing and others potentialities of yeasts remain to discover. New developments in engineering pathways in yeast using system biology and rDNA technologies have introduced novel capabilities to extend substrate range, to improve cellular properties and to produce new products yeast cannot produce. Yeasts nanobiotechnological application is a new field and other complex products can be produced through yeasts. With their medical utilization, yeasts are the most important industrial microorganisms. Also, many yeasts species have strong oxidative metabolism that enables the bioremediation and degradation of chemicals, pollutants such as aromatic compounds, plastics, and other recalcitrant compounds and polymers. These advances provide important strategies and tools for enhancing the biotechnological importance of yeasts. But, there is not enough information on yeasts nanobiotechnological application and a reviewed article on this topic will allow more information about yeasts and will increase their application for human interest and environment protection.

\section{Acknowledgments:-}

The authors wish to thank the Germany DAAD service for the financial support to one of the authors (MOGMENGA Iliassou) through it In Region/In country scholarship program in the University of Nigeria Nsukka. We need also to thank International Sciences Program (ISP, Sweden) for the financial support through the Research Center in Biological Food and Nutritional Sciences, Department of Biochemistry and Microbiology, University Ouaga I, Prof. Joseph KI-ZERBO.

\section{References:-}

1. Abubaker, H. O., Sulieman, A. M. E. and Elamin, H. B. (2012) 'Utilization of Schizosaccharomyces pombe for Production of Ethanol from Cane Molasses', Journal of Microbiology Research, 2(2), pp. 36-40. doi: 10.5923/j.microbiology.20120202.06.

2. Achi, O. K. and Ukwuru, M. (2015) 'Cereal-Based Fermented Foods of Africa as Functional Foods', International Journal of Microbiology and Application, 2(4), pp. 71-83.

3. Ahmed, S., Mustafa, G., Arshad, M. and Rajoka, M. I. (2017) 'Fungal Biomass Protein Production from Trichoderma harzianum Using Rice Polishing', BioMed Research International, 1, pp. 1-9. doi: $10.1155 / 2017 / 6232793$.

4. Akabanda, F., Owusu-kwarteng, J., Tano-debrah, K., Parkouda, C. and Jespersen, L. (2014) 'The Use of Lactic Acid Bacteria Starter Culture in the Production of Nunu, a Spontaneously Fermented Milk Product in Ghana', International Journal of Food Science. Hindawi Publishing Corporation, 1, pp. 1-11. doi: 10.1155/2014/721067.

5. Akanni, G. B., Preez, J. C., Steyn, L. and Kilian, S. G. (2014) 'Protein enrichment of an Opuntia ficus-indica cladode hydrolysate by cultivation of Candida utilis and Kluyveromyces marxianus', Journal of the Science of Food and Agriculture, 95, pp. 194-1102. doi: 10.1002/jsfa.6985.

6. Ali, S., Mushtaq, J., Nazir, F. and Sarfraz, H. (2017) 'Production and processing of Single Cell Protein (SCP) A review', European Pournal of Pharmaceutical and Medical Research, 4(7), pp. 86-94.

7. Anvari, M., Khayati, G., Branch, R. and Faculty, T. (2011) 'Submerged Yeast Fermentation of Cheese Whey for Protein Production and Nutritional Profile Analysis 1', Advance Journal of Food Science and Technology, 3(2), pp. 122-126.

8. Atter, A., Obiri-Danso, K. and Amoa-Awua, W. K. (2014) 'Microbiological and chemical processes associated with the production of burukutu a traditional beer in Ghana', International Food Research Journal, 21(5), pp. 1769-1776.

9. Awan, A. R., Blount, B. A., Bell, D. J., Shaw, W. M., Ho, J. C. H., Mckiernan, R. M. and Ellis, T. (2017) 'Biosynthesis of the antibiotic nonribosomal peptide penicillin in baker's yeast', Nature Communications. Nature Publishing Group, 8(5), pp. 1-8. doi: 10.1038/ncomms15202. 
10. Badia, R., Brufau, M. T., Guerrero-zamora, A. M., Lizardo, R., Dobrescu, I., Martin-venegas, R., Ferrer, R., Salmon, H., Martínez, P. and Brufau, J. (2012) ? $\beta$-Galactomannan and Saccharomyces cerevisiae var. boulardii Modulate the Immune Response against Salmonella enterica Serovar Typhimurium in Porcine Intestinal Epithelial and Dendritic Cells', Clinical and Vaccine Immunology, 19(3), pp. 368-376. doi: 10.1128/CVI.05532-11.

11. Baeshen, N. A., Baeshen, M. N., Sheikh, A., Bora, R. S., Ahmed, M. M. M., Ramadan, H. A. I., Saini, K. S. and Redwan, E. M. (2014) 'Cell factories for insulin production', Microbial Cell Factories, 13(141), pp. 1-9.

12. Bhalla, S. T. C. (2017) 'Yeasts and Traditional Fermented Foods and Beverages', in Yeast Diversity in Human Welfare, pp. 53-82. doi: 10.1007/978-981-10-2621-8_3.

13. Blandino, A., Al-aseeri, M. E., Pandiella, S. S., Cantero, D. and Webb, C. (2003) 'Cereal-based fermented foods and beverages', Food Research International, 36, pp. 527-543. doi: 10.1016/S0963-9969(03)00009-7.

14. Cereghino, G. P. L. and Cregg, J. M. (1999) 'Applications of yeast in biotechnology: protein production and genetic analysis', Current Opinion in Biotechnology, 10, pp. 422-427.

15. Chatterjee, S., Ghosh, B. and Ray, R. R. (2011) 'Isolation and characterization of local yeast strains from waste fruit juices , jaggery and dahi samples’, Int. J. Chem. Sci., 9(2), pp. 647-656.

16. Cyert, M. S. and Philpott, C. C. (2013) 'Regulation of Cation Balance in Saccharomyces cerevisiae', Genetics, 193, pp. 677-713. doi: 10.1534/genetics.112.147207.

17. Czerucka, D., Piche, T. and Rampal, P. (2007) 'Review article: Yeast as probiotics - Saccharomyces boulardii', Alimentary Pharmacology and Therapeutics, 26(6), pp. 767-778. doi: 10.1111/j.1365-2036.2007.03442.x.

18. Dimova, N. D., Iovkova, Z. S., Brinkova, M. and Godjevargova, T. I. (2010) 'Production of Candida biomass from hydrolysed agricultural biowaste', Biotechnol. \& Biotechnol. Eq., 24(1), pp. 1577-1581. doi: 10.2478/v10133-010-0008-4.

19. Djêgui, K. Y., Pierre, A., Kayodé, P., Tokpohozin, E. S., Gachomo, E. W., Kotchoni, S. O. and Hounhouigan, J. D. (2015) 'Phenotypic characters of yeasts isolated from Kpete-Kpete, a traditional starter of a Benin opaque sorghum beer', African Journal of Biotechnology, 14(27), pp. 2227-2233. doi: 10.5897/AJB2014.13895.

20. Djegui, Y. K., Kayodé, A. P. P. K., A.Raymond, A., Gachomo, E. W., Kotchoni, S. O. and Hounhouigani Joseph Djidjoho (2014) 'Diversit ty of yeasts in otchè , a traditional starter used in fermentation of an opaque sorghum beer "chakpalo", African Journal of Micr biology Research, 8(37), pp. 3398-3404. doi: 10.5897/A AJMR2014.6868.

21. Douradinha, B., Reis, V. C. B., Rogers, M. B., Torres, F. A. G., Evans, J. D. and Marques, E. T. A. (2014) 'Novel insights in genetic transformation of the probiotic yeast Saccharomyces boulardii', Bioengineered, 5(1), pp. 21-29. doi: 10.4161/bioe.26271.

22. El-Nawwi, S. A. and El-Kader, A. A. (1996) 'Production of single-cell protein and cellulase from sugarcane bagasse: Effect of culture factors', Biomass and Bioenergy, 11(4), pp. 361-364. doi: 10.1016/09619534(96)00021-9.

23. Evaldas, Č., Samuel, D., Juozapaitis, M., Sasnauskas, K. and Slibinskas, R. (2011) 'Overexpression of human virus surface glycoprotein precursors induces cytosolic unfolded protein response in Saccharomyces cerevisiae’, Microbial Cell Factories, 10(37), pp. 1-18. doi: 10.1186/1475-2859-10-37.

24. Fakruddin, M., Hossain, M. N. and Ahmed, M. M. (2017) 'Antimicrobial and antioxidant activities of Saccharomyces cerevisiae IFST062013, a potential probiotic', BMC Complementary and Alternative Medicine. BMC Complementary and Alternative Medicine, 17(64), pp. 1-11. doi: 10.1186/s12906-017-1591-9.

25. Fguiri, I., Ziadi, M., Abassi, M. and Arroum, S. (2012) 'Suitability of camel milk to transformation in Leben by lactic starter', African Journal of Microbiology Research, 6(44), pp. 7185-7192. doi: 10.5897/AJMR12.885.

26. Fonseca, G. G., Heinzle, E., Wittmann, C. and Gombert, A. K. (2008) 'The yeast Kluyveromyces marxianus and its biotechnological potential', Appl Microbiol Biotechnol (2008), 79, pp. 339-354. doi: 10.1007/s00253008-1458-6.

27. Franz, C. M. A. P., Huch, M., Maina, J., Abriouel, H., Benomar, N., Reid, G., Galvez, A. and Holzapfel, W. H. (2014) 'African fermented foods and probiotics', International Journal of Food Microbiology. Elsevier B.V., 190, pp. 84-96. doi: 10.1016/j.ijfoodmicro.2014.08.033.

28. Glover, R. L. K., Sawadogo-Lingani, H., Diawara, B., Jespersen, L. and Jakobsen, M. (2009) 'Utilization of Lactobacillus fermentum and Saccharomyces cerevisiae as starter cultures in the production of " dolo ", Journal of Applied Biosciences, 22, pp. 1312-1319.

29. Graf, A., Dragosits, M., Gasser, B. and Mattanovich, D. (2009) 'Yeast systems biotechnology for the production of heterologous proteins', FEMS Yeast Res, 9, pp. 335-348. doi: 10.1111/j.15671364.2009.00507.x. 
30. Greppi, A., Rantisou, K., Padonou, W., Hounhouigan, J., Jespersen, L., Jakobsen, M. and Cocolin, L. (2013a) 'Yeast dynamics during spontaneous fermentation of mawè and tchoukoutou, two traditional products from Benin.', International Journal of Food Microbiology. Elsevier B.V., 165, pp. 200-207. doi: 10.1016/j.ijfoodmicro.2013.05.004.

31. Greppi, A., Rantsiou, K., Padonou, W., Hounhouigan, J., Jespersen, L., Jakobsen, M. and Cocolin, L. (2013b) 'Determination of yeast diversity in ogi , mawè , gowé and tchoukoutou by using culture-dependent and independent methods', International Journal of Food Microbiology. Elsevier B.V., 165(2), pp. 84-88. doi: 10.1016/j.ijfoodmicro.2013.05.005.

32. Guc, S. and Erkmen, O. (2017) 'Citric Acid Production from Nontreated Beet Molasses by a Novel Aspergillus niger Strain: Effects of pH, Sugar and Ingredients', Journal of Food: Microbiology, Safety \& Hygiene, 2(2), pp. 1-5. doi: 10.4172/2476-2059.1000122.

33. Gupta, A. and Prakash, J. (2015) 'Sustainable bio-ethanol production from agro-residues: A review', Renewable and Sustainable Energy Reviews. Elsevier, 41, pp. 550-567. doi: 10.1016/j.rser.2014.08.032.

34. Gupta, R., Kumari, A., Syal, P. and Singh, Y. (2015) 'Progress in Lipid Research Molecular and functional diversity of yeast and fungal lipases: Their role in biotechnology and cellular physiology', Progress in Lipid Research. Elsevier Ltd, 57, pp. 40-54. doi: 10.1016/j.plipres.2014.12.001.

35. Hamad, S. H., Dieng, M. C., Ehrmann, M. A. and Vogel, R. F. (1997) 'Characterization of the bacterial flora of Sudanese sorghum flour and sorghum sourdough', Journal of Applied Microbiology, 83, pp. 764-770.

36. Hatoum, R., Labrie, S. and Fliss, I. (2012) 'Antimicrobial and probiotic properties of yeasts : from fundamental to novel applications', Frontier in Microbiology, 3(421), pp. 1-12. doi: 10.3389/fmicb.2012.00421.

37. Hull, C. M., Loveridge, E. J., Donnison, I. S., Kelly, D. E. and Kelly, S. L. (2014) 'Co-production of bioethanol and probiotic yeast biomass from agricultural feedstock: application of the rural biorefinery concept', AMB Express, 4(64), pp. 1-8. doi: 10.1186/s13568-014-0064-5.

38. Iannotti, L. and Lesorogol, C. (2014) 'Animal milk sustains micronutrient nutrition and child anthropometry among pastoralists in Samburu, Kenya', Am. J. Phys. Anthropol., 155(1), pp. 66-76. doi: 10.1002/ajpa.22547.

39. Ilmén, M., Koivuranta, K., Ruohonen, L., Rajgarhia, V., Suominen, P. and Penttilä, M. (2013) 'Production of Llactic acid by the yeast Candida sonorensis expressing heterologous bacterial and fungal lactate dehydrogenases', Microbial Cell Factories, 12(53), pp. 1-15. doi: 10.1186/1475-2859-12-53.

40. Jans, C., Meile, L., Wambua, D., Kaindi, M., Kogi-makau, W., Lamuka, P., Renault, P., Lacroix, C., Hattendorf, J., Schelling, E., Fokou, G., Bonfoh, B., Hattendorf, J., Zinsstag, J., Schelling, E. and Fokou, G. (2017) 'African fermented dairy products - overview of predominant technologically important microorganisms focusing on African Streptococcus infantarius variants and potential future applications for enhanced food safety and security', International Journal of Food Microbiology. Elsevier B.V, 250, pp. 27-36. doi: 10.1016/j.ijfoodmicro.2017.03.012.

41. Johnson, E. A. (2013) 'Biotechnology of non- Saccharomyces yeasts — the basidiomycetes', Appl Microbiol Biotechnol, 97, pp. 7563-7577. doi: 10.1007/s00253-013-5046-Z.

42. Johnson, E. A. and Echavarri-Erasun, C. (2011) 'Yeast biotechnology', in The Yeasts. Fifth, pp. 21-44. doi: 10.1016/B978-0-444-52149-1.00003-3.

43. Kayodé, A. P. P., Deh, D. C., Baba-moussa, L., Kotchoni, S. O. and Hounhouigan, J. D. (2012) 'Stabilization and preservation of probiotic properties of the traditional starter of African opaque sorghum beers', African Journal of Biotechnology, 11(30), pp. 7725-7730. doi: 10.5897/AJB11.3231.

44. Kebede, A., Viljoen, B. C., Gadaga, T. H., Narvhus, J. A. and Lourens-Hattingh, A. (2007) 'The effect of container type on the growth of yeast and lactic acid bacteria during production of Sethemi, South African spontaneously fermented milk', Food Research International, 40(1), pp. 33-38. doi: 10.1016/j.foodres.2006.07.012.

45. Konlani, S., Delgenes, J. P., Moletta, R., Traore, A. and Doh, A. (1996) 'Optimization of cell yield of Candida krusei SO1 and Saccharomyces sp. LK3G cultured in sorghum hydrolysate', Bioresource Technology, 57, pp. 275-281.

46. Kubo, R. and Kilasara, M. (2016) 'Brewing Technique of Mbege, a Banana Beer Produced in Northeastern Tanzania', Beverages, 2(3), p. 21. doi: 10.3390/beverages2030021.

47. Lara-Hidalgo, C., Hernández-Sánchez, H., Hernández-Rodríguez, C. and Dorantes-Álvarez, L. (2017) 'Yeasts in Fermented Foods and their Probiotic Potential', Austin Journal of Nutrition \& Metabolism, 4(1), pp. 1-8.

48. Laurent-babot, C. and Guyot, J. (2017) 'Should Research on the Nutritional Potential and Health Benefits of Fermented Cereals Focus More on the General Health Status of Populations in Developing Countries?', Microorganisms, 5(40), pp. 1-10. doi: 10.3390/microorganisms5030040. 
49. Liu, L., Martinez Ruiz, J. and Liu, Z. (2014) 'Chalmers Publication Library Balanced globin protein expression and heme biosynthesis improve production of human hemoglobin in Saccharomyces cerevisiae', Metabolic Engineering, 21, pp. 9-16. doi: 10.1016/j.ymben.2013.10.010.

50. Lore, T. A., Mbugua, S. K. and Wangoh, J. (2005) 'Enumeration and identification of microflora in suusac, a Kenyan traditional fermented camel milk product', Lebensm.-Wiss. u.-Technol., 38, pp. 125-130. doi: 10.1016/j.lwt.2004.05.008.

51. Lyumugabe, F., Uyisenga, J. P., Songa, E. B. and Thonart, P. (2014) 'Production of Traditional Sorghum Beer “ Ikigage " Using Saccharomyces cerevisae, Lactobacillus fermentum and Issatckenkia orientalis as Starter Cultures', Food and Nutrition Sciences, 5, pp. 507-515. doi: 10.4236/fns.2014.56060.

52. Martinez, R. J., Liu, L. and Petranovic, D. (2012) 'Pharmaceutical protein production by yeast: towards production of human blood proteins by microbial fermentation', Current Opinion in Biotechnology, 23(6), pp. 965-971.

53. Mcfarland, L. V (2010) 'Systematic review and meta-analysis of Saccharomyces boulardii in adult patients', World Journal Gastroenterol, 16(18), pp. 2202-2222. doi: 10.3748/wjg.v16.i18.2202.

54. Mcfarland, L. V (2015) 'Probiotics for the Primary and Secondary Prevention of C. difficile Infections: A Metaanalysis and Systematic Review’, antibiotics, 4, pp. 160-178. doi: 10.3390/antibiotics4020160.

55. Meena, V., Sobha, K., Sambasiva Rao, K. R. S. and Subbarathinam, K. M. (2010) 'A Comparative Study of Kinetics of Itaconic Acid Production Using Four Species of the Genus Aspergillus', International Journal of Genetic Engineering and Biotechnology, 1(3), pp. 165-176.

56. Meena, V., Sumanjali, A., Dwarka, K., Subburathinam, K. M. and Rao, K. R. S. S. (2010) 'Production of itaconic acid through submerged fermentation employing different species of Aspergillus', Rasayan J. Chem., 3(1), pp. 100-109.

57. Mogmenga, I., Somda, K. M., Keita, I. and Traoré, A. S. (2017) 'Evaluation of hygienic quality of ferment of local beer " dolo" used as condiment in Burkina Faso', African Journal of Biotechnology, 16(26), pp. 14491456. doi: 10.5897/AJB2017.16061.

58. Mugula, J. K., Nnko, S. A. M., Narvhus, J. A. and Sørhaug, T. (2003) 'Microbiological and fermentation characteristics of togwa, a Tanzanian fermented food', International Journal of Food Microbiology, 80, pp. 187-199.

59. Nangul, A. and Bhatia, R. (2013) 'Microorganisms : A marvelous source of Single Cell Proteins', Journal of Microbiology, Biotechnology and Food Sciences, 3(1), pp. 15-18.

60. Nasseri, a. T., Rasoul-Amini, S., Morowvat, M. H. and Ghasemi, Y. (2011) 'Single Cell Protein: Production and Process', American Journal of Food Technology, 6(2), pp. 103-116. doi: 10.3923/ajft.2011.103.116.

61. Nieminen, M. T., Novak-Frazer, L., Collins, R., Dawsey, S. P., Dawsey, S. M., Abnet, C. C., White, R. E., Freedman, N.D., Mwachiro, M., Bowyer, P., Salaspuro, M. and Rautemaa, R. (2013) 'Alcohol and acetaldehyde in African fermented milk mursik-a possible Epidemiol., factor for high incidence of esophageal cancer in western Kenya.', Cancer Biomark. Prev., 22, pp. 69-75. doi: 10.1158/1055-9965.EPI-12-0908.

62. Nyambane, B., Thari, W. M., Wangoh, J. and Njage, P. M. (2014) 'Lactic acid bacteria and yeasts involved in the fermentation of amabere amaruranu, a Kenyan fermented milk.', Food Sci. Nutr., 2, pp. 692-699. doi: $10.1002 / \mathrm{fsn} 3.162$.

63. Oguntoyinbo, F. A., Tourlomousis, P., Gasson, M. J. and Narbad, A. (2011) 'Analysis of bacterial communities of traditional fermented West African cereal foods using culture independent methods', International Journal of Food Microbiology. Elsevier B.V., 145(1), pp. 205-210. doi: 10.1016/j.ijfoodmicro.2010.12.025.

64. Olanbiwoninu, A. A., Irokosu, O. and Odunfa, S. A. (2017) 'Riboflavin enriched iru: A fermented vegetable protein', African Journal of Biotechnology, 11(13), pp. 546-552. doi: 10.5897/AJMR2016.8317.

65. Olasupo, N. A., Odunfa, S. A. and Obayori, O. S. (2010) 'Ethnic African fermented foods', in J. P. Tamang and K. Kailasapathy (New York, NY: CRC Press, T. and F. G. (ed.) Fermented Foods and Beverages of the World, pp. 323-352. doi: 10.1201/ebk1420094954-c12.

66. Olempska-Beer, Z. S., Merker, R. I., Ditto, M. D. and DiNovi, M. J. (2006) 'Food-processing enzymes from recombinant microorganisms--a review Food-processing enzymes from recombinant microorganisms - a review', Regulatory Toxicology and Pharmacology, 45, pp. 144-158. doi: 10.1016/j.yrtph.2006.05.001.

67. Ouedraogo, N., Savadogo, A., Somda, M. K., Tapsoba, F. and Traore, A. S. (2017) 'Effect of mineral salts and nitrogen source on yeast (Candida utilis NOY1) biomass production using tubers wastes', African Journal of Biotechnology, 16(8), pp. 359-365. doi: 10.5897/AJB2016.15801.

68. Ouédraogo, N., Savadogo, A., Somda, M. K., Zongo, C. and Traore, A. S. (2012) 'Essai de production de protéines d'organismes unicellulaires par des souches de levures à partir de résidus de tubercules de patate douce et d' igname', Biotechnol. Agron. Soc. Environ., 16(4), pp. 463-467. 
69. Ouoba, L. I. I., Parkouda, C., Diawara, B., Scotti, C. and Varnam, A. H. (2008) 'Identification of Bacillus spp .from Bikalga , fermented seeds of Hibiscus sabdariffa : phenotypic and genotypic characterization', Journal of Applied Microbiology, 104, pp. 122-131. doi: 10.1111/j.1365-2672.2007.03550.x.

70. Pimenta, R. S., Morais, P. B., Rosa, C. A. and Correa, A. (2009) 'Utilization of yeasts in biological control programs', in Yeast biotechnology: diversity and applications. Springer, pp. 199-214.

71. Pohnerkar, J. K. and Desai, S. A. (2014) 'Selective Synthesis of Citric Acid from Molasses using Aspergillus niger', International Journal of Engineering Trends and Technology, 9(1), pp. 7-9.

72. Quigley, L., O’Sullivan, O., Stanton, C., Beresford, T. P., Ross, R. P., Fitzgerald, G. F. and Cotter, P. D. (2013) 'The complex microbiota of raw milk', FEMS Microbiology Reviews, 37(5), pp. 664-698. doi: 10.1111/15746976.12030.

73. Rodríguez-Limas, W. A., Tyo, K. E. J., Nielsen, J., Ramírez, O. T. and Palomares, L. A. (2011) 'Molecular and process design for rotavirus-like particle production in Saccharomyces cerevisiae', Microbial Cell Factories. BioMed Central Ltd, 10(1), p. 33. doi: 10.1186/1475-2859-10-33.

74. Salvachúa, D., Mohagheghi, A., Smith, H., Bradfield, M. F. A., Nicol, W., Black, B. A., Biddy, M. J., Dowe, N. and Beckham, G. T. (2016) 'Biotechnology for Biofuels Succinic acid production on xylose - enriched biorefinery streams by Actinobacillus succinogenes in batch fermentation', Biotechnology for Biofuels. BioMed Central, 9(28), pp. 1-15. doi: 10.1186/s13068-016-0425-1.

75. Samet-Bali, O., Felfoul, I., Lajnaf, R., Attia, H. and Ayadi, M. A. (2017) 'Enumeration and identification of microflora in "Leben ", a traditional Tunisian dairy beverage', International Food Research Journal, 24(3), pp. 927-932.

76. Sarkar, P. K., Hasenack, B. and Nout, M. J. R. (2002) 'Diversity and functionality of Bacillus and related genera isolated from spontaneously fermented soybeans (Indian Kinema) and locust beans ( African Soumbala )', International Journal of Food Microbiology, 77, pp. 175-186.

77. Sauer, M., Porro, D., Mattanovich, D. and Branduardi, P. (2008) 'Microbial production of organic acids: expanding the markets', Trends in Biotechnology, 26(2), pp. 100-108. doi: 10.1016/j.tibtech.2007.11.006.

78. Savadogo, A., Savadogo, P. W., Ouattara, A. S., Barro, N. and Traore, A. S. (2004) 'Microorganisms Involved in Fulani Traditional Fermented Milk in Burkina Faso', Pakistan Journal of Nutrition, 3(2), pp. 134-139.

79. Sawadogo-Lingani, H., Diawara, B., Glover, R. K., Tano-Debrah, K., Traoré, A. S. and Jakobsen, M. (2010) 'Predominant lactic acid bacteria associated with the traditional malting of sorghum grains', African Journal of Microbiology Research, 4(3), pp. 169-179.

80. Schisler, D. A., Janisiewicz, W. J., Boekhout, T. and Kurtzman, C. P. (2010) 'Agriculturally important yeasts: biological control of field and postharvest diseases using yeast antagonists, and yeasts as pathogens of plants', in The Yeasts. Fifth, pp. 45-52. doi: 10.1016/B978-0-444-52149-1.00004-5.

81. Schisler, D. ., Slininger, P. ., Boehm, M. and Paul, P. . (2011) 'Co-culture of Yeast Antagonists of Fusarium Head Blight and their Effect on Disease Development in Wheat', Plant Pathology Journal, 10(4), pp. 128-137. doi: 10.3923/ppj.2011.128.137.

82. Scoma, A., Coma, M., Kerckhof, F. M., Boon, N. and Rabaey, K. (2017) 'Biotechnology for Biofuels Efficient molasses fermentation under high salinity by inocula of marine and terrestrial origin', Biotechnology for Biofuels. BioMed Central, 10(23), pp. 1-17. doi: 10.1186/s13068-017-0701-8.

83. Seo, H., Um, H., Min, J., Rhee, S., Cho, T., Kim, Y. and Lee, J. (2007) 'Ustilaginomycetous yeast species that is able to degrade plastic waste', FEMS Yeast Res, 7, pp. 1035-1045. doi: 10.1111/j.1567-1364.2007.00251.x.

84. Singh, G., Sunil, D., Harinder, B. and Oberoi, S. (2007) 'Caulifl ower waste incorporation into cane molasses improves ethanol production using Saccharomyces cerevisiae MTCC 178', Indian J. Microbiol., 47, pp. 353357.

85. Singhania, R. R., Saini, J. K., Saini, R., Adsul, M., Mathur, A., Gupta, R. and Tuli, D. K. (2014) 'Bioethanol production from wheat straw via enzymatic route employing Penicillium janthinellum cellulases', Bioresource Technology, 169, pp. 490-495.

86. Somda, K., Savadogo, A., Barro, N., Thonart, P. and Traoré, A. S. (2011) 'Effet of minerals Salts in Fermentation Process using Mango Residues as Carbon Source for Bioethanol Production', Asian Journal of Industrial Engieneering, 3(1), pp. 29-38. doi: 10.3923/ajie.2011.29.38.

87. Somda, M. K., Ouattara, A. C. T., Mogmenga, I., Keita, I., Ouedraogo, N., Traore, D. and Traore, A. S. (2017) 'Optimization of Saccharomyces cerevisiae SKM10 single cell protein production from mango (Magnifera indica L.) waste using response surface methodology', African Journal of Biotechnology, 16(45), pp. 21272133. doi: 10.5897/AJB2017.16210. 
88. Steensels, J., Snoek, T., Meersman, E., Nicolino, M. P., Voordeckers, K. and Verstrepen, K. J. (2014) 'Improving industrial yeast strains: exploiting natural and artificial diversity', FEMS Microbiology Reviews, 38, pp. 947-995. doi: 10.1111/1574-6976.12073.

89. Suman, G., Nupur, M., Anuradha, S. and Pradeep, B. (2015) 'Review Article Single Cell Protein Production : A Review', Int.J.Curr.Microbiol.App.Sci, 4(9), pp. 251-262.

90. Suzuki, C., Ando, Y. and Machida, S. (2001) 'Interaction of SMKT, a killer toxin produced by Pichia farinosa, with the yeast cell membranes', Yeast, 18, pp. 1471-1478. doi: 10.1002/yea.791.

91. Tamang, J. P., Watanabe, K. and Holzapfel, W. H. (2016) 'Review: Diversity of Microorganisms in Global Fermented Foods and Beverages’, Frontier in Microbiology, 7(377), pp. 1-28. doi: 10.3389/fmicb.2016.00377.

92. Tankoano, A., Sawadogo-lingani, H., Savadogo, A., Kabore, D. and Traore, Y. (2017) 'Study of the process and microbiological quality of Gappal, a fermented food from Burkina Faso based on milk and millet dough', International Journal of Multidisciplinary and Current Research, 5, pp. 104-110.

93. Tomo, N., Goto, T. and Morikawa, Y. (2013) 'Trans-packaging of human immunodeficiency virus type 1 genome into Gag virus-like particles in Saccharomyces cerevisiae', Microbial Cell Factories, 12(23), pp. 1-13. doi: 10.1186/1475-2859-12-28.

94. Türker, M. (2014) 'Yeast Biotechnology: Diversity and Applications Yeast Biotechnology: Diversity and Applications', in Istanbul. Advances in Science and Industrial Productionss of Baker's Yeast, pp. 1-26.

95. Vanz, A. L., Lünsdorf, H., Adnan, A., Nimtz, M., Gurramkonda, C., Khanna, N. and Rinas, U. (2012) 'Physiological response of Pichia pastoris GS115 to methanol-induced high level production of the Hepatitis B surface antigen : catabolic adaptation, stress responses, and autophagic processes', Microbial Cell Factories, 11(103), pp. 1-11. doi: 10.1186/1475-2859-11-103.

96. Vieira-Dalodé, G., Jespersen, L., Hounhouigan, J., Moller, P. L., Nago, C. M. and Jakobsen, M. (2007) 'Lactic acid bacteria and yeasts associated with gowe ' nin production from sorghum in Be', Journal of Applied Microbiology, 103, pp. 342-349. doi: 10.1111/j.1365-2672.2006.03252.x.

97. Watanabe, T., Iefuji, H. and Kitamoto, H. K. (2013) 'Treatment of, and Candida utilis biomass production from shochu wastewater; the effects of maintaining a low $\mathrm{pH}$ on DOC removal and feeding cultivation on biomass production', SpringerPlus, 2(514), pp. 1-7.

98. Wijeyaratne, S. C. and Jayathilakf, A. N. (2000) 'Characteristics of two yeast strains (Candida tropicalis) isolated from caryota urens kitthul toddy for Single Cell Protein production', J. Natn. Sci. Foundation Sri Lanka, 28(1), pp. 79-86.

99. Willaert, R. G. (2017) 'Yeast Biotechnology', Fermentation, 3(6), pp. 6-8. doi: 10.3390/fermentation3010006.

100.Willaert, R., Kasas, S., Devreese, B. and Dietler, G. (2016) 'Yeast Nanobiotechnology', Fermentation, 2(18), pp. 1-37. doi: 10.3390/fermentation2040018.

101.Witthuhn, R. C., Schoeman, T. and Britz, T. J. (2004) 'Isolation and characterization of the microbial population of different South African kefir grains.', International Journal of Dairy Technology, 57(1), pp. 3337. doi: 10.1111/j.1471-0307.2004.00126.x.

102. Yalcin, S. K., Bozdemir, M. T. and Ozbas, Z. Y. (2010) 'Citric acid production by yeasts: Fermentation conditions , process optimization and strain improvement’, pp. 1374-1382.

103.Zabed, H., Faruq, G., Sahu, J. N., Azirun, M. S., Hashim, R. and Boyce, A. N. (2014) 'Bioethanol Production from Fermentable Sugar Juice’, The Scientific World Journal, 1, pp. 1-11. doi: 10.1155/2014/957102. 